\title{
THE PROSPECT OF ASEAN MIGRATION GOVERNANCE ${ }^{1}$
}

\author{
Sylvia Yazid ${ }^{2}$ and lyan Septiyana ${ }^{3}$ \\ ${ }^{2}$ International Relations Study Program, Universitas Katolik Parahyangan, Bandung, Indonesia \\ ${ }^{3}$ International Relations Study Program, Universitas Pasundan, Bandung, Indonesia \\ Corresponding Author Email: s_yazid@unpar.ac.id
}

\begin{abstract}
ASEAN member countries are migrant-sending and receiving countries. Around 7.3 million of ASEAN citizens are migrant workers, more than 740 thousand of them are refugees from Myanmar, and a significant number are victims of human trafficking. They frequently receive discriminatory treatment, which violate their human rights. ASEAN, as a regional organization, is an actor that is expected to implement migration governance in the region. ASEAN has a number of instruments related to human trafficking and migrant workers in the forms of documents and specific regional bodies. However, ASEAN is criticized for not being able to utilize its instruments to comprehensively conduct a regional governance of migration. This paper discusses the prospects of ASEAN migration governance in actually resolving migration issues in the region.
\end{abstract}

Keywords: ASEAN, Migration, regional governance, migration governance, human rights

\begin{abstract}
Abstrak
Negara anggota ASEAN merupakan negara pengirim dan penerima migran. Sekitar 7,3 juta penduduk ASEAN merupakan buruh migran, lebih dari 74oribu orang merupakan pengungsi yang berasal dari Rohingya, dan sejumlah besar dari korban perdagangan orang merupakan warga negara ASEAN. Seringkali para migran tersebut mendapatkan perlakuan diskriminatif, yang melanggar hak-hak asasi mereka. ASEAN sebagai sebuah organisasi regional merupakan aktor yang diharapkan dapat menjalankan tata kelola regional migrasi di kawasan. ASEAN memiliki beberapa instrumen yang terkait dengan perdagangan manusia dan pekerja migran dalam bentuk dokumen dan badan-badan regional. Namun ASEAN masih dikritik karena tidak mampu memanfaatkan instrument tersebut untuk secara komprehensif melaksanakan tata kelola migrasi secara regional. Tulisan ini mendiskusikan prospek dari tata kelola migrasi ASEAN dalam menangani isu-isu migrasi di kawasan.
\end{abstract}

Kata kunci: ASEAN, Migrasi, tata kelola regional, tata kelola migrasi, Hak asasi manusia

I Both authors contribute equally to this work 


\section{INTRODUCTION}

Simply defined, migration is the activity of moving people from one country to another, hat is temporary or permanent, mostly to seek for better living conditions. The most common reasons are economic, in the search for employment opportunities or political as an effort to escape from poverty, repression or conflict (Wynne, 2015). People who migrate or migrants can generally be categorized into various classifications such as permanent residents, high and low ability expatriates, asylum seekers, refugees, undocumented workers, visa-free migrants, students, and many others (Goldin \& Reinert, 2007).

Migration flows in the Asian region cannot be quantified into an exact number because there is no integrated data among the countries, including in the Southeast Asian area. Furthermore, the estimated number of migrant flows should be made by referring to the data of both regular and irregular migration. Regular migration, such as documented workers or family reunions, can be quantified because usually the state has and keeps the statistics of these migrants. Meanwhile, for irregular migration such as migrants who have expired visas or asylum seekers, getting the exact number can be challenging because there is limited or no data about them (Raymer, Guan, \& Ha, 20I8).

The International Organization for Migration (IOM) classifies migrants into four categories, namely young and child migrants, migrant workers, forced migration and displacement, and return migration (IOM, 20I9d). The 2017 data shows that the number of children and young migrants in the Asian region, including ASEAN, is more than 40 million (IOM, 20I9a), while the number of migrant workers in the ASEAN region globally is around 2I.3 million, and about 7.3 million of them are intra-regional migrant workers (ILO, 20I5). ASEAN also contributed to the number of forced and displaced migrants from Myanmar (IOM, 20I9b; Raymer et al., 20I8). About $68 \%$ of migrants who return to their home countries either voluntarily or coercively come from ASEAN countries such as Indonesia, Thailand, and Malaysia (IOM, 20I9c).
These migrants often face discrimination or even experience oppression of which violate their human rights. For example, migrant workers often become victims of social and political rights violations in a community by being excluded from government policies both in their origin and destination countries (Olivier, 2018). In an even worse condition, many refugees, such as Rohingya people, have become victims of discrimination, violence, persecution, and even murder. In 2018 there were 6700 Rohingyas killed, and 730 of them were children under five years old (Mahmud, Khaled, \& Fariba, 2019). The phenomenon reflects the worrying state of human rights issues in the region amid the effort of ASEAN to advance its human rights agenda as reflected in its Charter (HumanrightsinASEAN, 2019). Thus, the issue of the rights of migrants has continuously become an urgent matter to be addressed by ASEAN as regional governance in the region.

The Universal Declaration of Human Rights of the United Nations in I948 (UDHR) is a primary instrument for human rights protection universally. Some of the derivatives for migrant rights protection then emerge such as the I95I Geneva Convention on Refugees), and the Declaration of the Rights of the Child in I959 as a legal basis for governing the issues of human migration (Goldin \& Reinert, 2007). These documents suggest the use of human rights as a basic approach to migrant protection issues.

ASEAN's commitment to human rights issues can be seen since 2004 through the ASEAN Security Community (ASC) plan, which included the agenda of human rights promotion cooperation (ASEAN_Secretariat, 2004; Kranrattanasuit, 2014) in the issue of migration as stipulated in the 2004 Vientiane Action Plan (VAP) document. Specifically, there are four instruments; namely the ASEAN Declaration Against Trafficking in Persons Particularly Women and Children in 2004 (ASEAN, 2004a); ASEAN Declaration on the Protection and Promotion of the Rights of Migrant Workers 2007; ASEAN Socio-Cultural Community (ASCC) Blueprint 2007; and the 20I7 ASEAN 
Consensus on the Protection and Promotion of the Rights of Migrant Workers.

To support ASEAN's performance in the issue of migration, ASEAN is assisted by several ASEAN bodies, including the ASEAN Intergovernmental Commission on Human Rights (AICHR), the ASEAN Committee on the Implementation of the ASEAN Declaration on the Protection and Promotion of the Rights of Migrant Workers (ACMW), and The ASEAN Commission on the Promotion and Protection of the Rights of Women and Children (ACWC). These regional instruments can be classified into two broad categories, namely policies on handling the issue of trafficking in persons and migrant workers. Meanwhile, at present, ASEAN is also facing the issue of displaced persons and refugees from Myanmar. The absence of specific policies and bodies comprehensively dealing with migration issues makes it challenging for ASEAN to govern migration within the region. Therefore, this paper will discuss the possibility or the prospect of ASEAN migration governance in handling current migration issues.

\section{THEORETICAL FRAMEWORKS}

Global governance is a term that describes the process of cooperation between national governments, multilateral institutions, and civil society to tackle cross-border problems (Boughton \& Jr, 2007; Finkelstein, I995). The process is cooperative actions with policymaking procedures to accommodate the different interests of actors involved, both state and non-state (Margaret P Karns, Karen A Mingst, \& Stilles, 2015; Weiss \& Wilkinson, 2014a). The actors come from local, national, and international levels with two-ways mechanism top-down and vice versa (Soederberg, 2006). Based on this concept, the actors involved in global governance are not only dominated by state actors. Hence, there is a diffused state power together with non-state actors that enable them to play in international politics that forms a new governance model (Guzzini, 20I2).

Intergovernmental organizations in a region can become an instrument for member states to deal with various problems. They can function as the extension or strengthen global governance institutions such as the United Nations (Fawcett, 2008; Haas, I958). The potency of it can be seen from the relations between the organization with its country members, its decision making mechanism, and the relations among the ministers that enable them to produce regional policies (Haas, I958), which can bind its member states. Therefore, regional organizations are considered to be more effective governance institutions, because they can run the system in a more specific context (Hadiprayitno, 2019).

The end of the cold war brought states to the economic competition in trade liberalization, which was supported by the process of globalization. Globalization can increase the economic level of a nation. However, on the other hand, it may also increase income differences between rich and developing countries and causing income inequality (Reinert, 2004). To be exact, the average income in a rich country has increased about 37 times the average of a developing country, and the gap has the potential to double (Borzutzky, 2003). These conditions lead to conditions of income inequality, where workers in developing countries receive minimum wages (The-Economist, 2003). The economic advancement of rich countries become one of the pull factors for people from developing countries to migrate in search of higher income or better conditions in richer developed countries (Kuptsch \& Martin, 2OII).

Nowadays, international migration becomes one of the issues of international politics, because in the process international migration crosses territorial borders between countries and has specific impacts on the country. Hence, the state needs to make a joint agreement or a precise regulatory mechanism in an international institution as a collective action in dealing with it (Betts, 20II). According to Aleinikoff, migration governance consists of 'substance without architecture' because of the existence of the norm, which is not accompanied by a specific institution (Betts, 20II). The evolving of the migration issue to be more complex, makes countries try to deal with it both bilaterally 
between receiving and sending countries, or through the framework of a regional institution (Kunz, Lavenex, \& Panizzon, 20II).

A regional organization potentially becomes a multi-problem governance institution, since some regional organizations expand its institutional orientation that is not only for security purposes but also broadened to political, economic, and social purposes (Fawcett, 2008). Thus, the multipurpose regional organizations can be a multilateral cooperation form for states to manage migration issues in a region. As part of global governance, the regional organization conduct collective effort to deal with common-problems, own problem-solving arrangements such as law both soft or hard, and certain institutional structures built by the actors involved such as the state, international organizations, non-governmental organizations and civil society (Weiss \& Wilkinson, 20I4b).

Based on Weiss and Wilkinson's argument, the authors identify that policies, probably in the form of agreements, and organization's supporting body are essential elements in regional governance. Hence, to carry out regional governance, regional organizations need to produce iddue related policies as instruments and supportingbodies that will help the policy implementation. Migration policies can address issues such as international travel, labor migration, irregular migration, human trafficking and smuggling, asylum and refugee protection, and displaced people (Betts, 20II). The complexity of issues related to migration and the different interests of the state make the states prefer to deal with issues related to migration through the mechanism of bilateral or multilateral consultation processes (Köhler, 20II).

The Regional Consultation Process (RCP) is a form of state consultation in a multilateral framework in a region that is usually associated with the formation of a regional economic community that allows free human movement intra-regions. The RCP is one of migration governance solutions in the absence of global migration management and can contribute to the convergence of global migration policies. $\mathrm{RCP}$ is a government network intended to bridge the country in the "international" sphere amid difference states' interests in international politics that do not have a central authority. It becomes state's instrument to regulate relations between them. Usually, the output of this network is a non-binding policy that agrees on consensus or adopts a solution based on best practices' through international comparison (Köhler, 20II).

ASEAN is a regional cooperation institution for Southeast Asian countries established in I967 and currently its members include Brunei Darussalam, Cambodia, Indonesia, Lao PDR, Malaysia, Myanmar, Philippines, Singapore, Thailand, and Vietnam. Its founding countriesestablished ASEAN with the aim to create peace and security and stability and prosperity in the region by promoting the principle of non-intervention in internal matters (http://setnas-asean.id/tentang-asean, 20I9). ASEAN develops its multi-dimensional regional cooperation by forming the ASEAN Community, which is supported by three pillars, namely ASEAN Economic Community (AEC), ASEAN Political-Security Community (APSC), and ASEAN Socio-Cultural Community (ASCC) (Liow, 2017). Within the ASEAN Community, it is also equipped with precise decision-making mechanisms, to enable ASEAN in becoming a multi-dimensional governance institution in the region for its member countries.

ASEAN is an intergovernmental institution that prioritizes the principle of nonintervention. The policymaking mechanism is decided through a consensus, where all parties must agree on a policy decision. The implementation of this system makes the level of institutionalization of ASEAN low and makes the policies produced by ASEAN is non-binding for its member countries, including in the governance of migration. The authors believe that ASEAN migration governance implements the Regional Consultation Process (RCP) because first, migration governance is more initiated based on economic interests. Second, there is no specific ASEAN body that is specifically a migration management body in the region. Third, ASEAN members do not transferparts of their sovereignty to intergovernmental 
institutions, thus there is no central authority in ASEAN. Fourth, the produced policies on migration issues are not binding for the member countries. The most urgent problem in ASEAN related to migration is the issue of human rights, hence the next section will discuss on ASEAN governance in handling human rights issues related to migration.

\section{ASEAN governance, human rights and migration issues}

ASEAN policy-making is state-centric, where policy-making is in the hands of the government and decided in the ASEAN Summit as the head of government meeting, ASEAN Ministerial Meeting (AMM) as a ministerial meeting, and sectoral body-level ministerial meetings (Septiyana, 2019). On the issue of migration, there are three governance sub-regions, namely the Greater Mekong Sub-region (GMS), Brunei-IndonesiaMalaysia-Philippines East Asian Growth Area (BIMP-EAGA), and Maritime Southeast Asia. Whereas in the term of governance model, there are three models, namely: ASEAN-X (minus some member countries who are still not ready to join in an agenda), ASEAN + (plus countries outside the region), and a combination of both (Aldaba, 20I4).

The first is GMS, an economic cooperation area, united by the Mekong River of 2.6 million square kilometers, formed by the Asian Development Bank (ADB) in 1992. Its territory covers some countries, such as the People's Republic of China (Yunan and the Guangxi Zhuan), Cambodia, Lao PDR, Myanmar, Thailand, and Viet Nam (ADB, 20I8). The region is an area of the labor movement with Thailand as the locus (Aldaba, 20I4). The second is BIMP-EAGA, established in 1994 by Brunei-Indonesia-Malaysia-Philippines. The pattern is the movement of labor migration from Mindanao Philippines and Indonesia to Brunei and Malaysia (Aldaba, 20I4 ). The third is the Southeast Asia Maritime region, whose territory extends to include Brunei, Indonesia, Malaysia, the Philippines, Singapore, and East Timor (Tarling, I999), or the ASEAN maritime region as a whole.
Human migration crossing national territory in various forms gains various responses from the people in the destination country. Often, migrants experience discriminatory treatment such as racism, xenophobia, antisemitism, and other forms of marginalization. Consequently, the basic human rights of migrant groups cannot be fulfilled because of discriminatory policies. Principally the norms of human rights are universal and applicable for all people, both local people and migrants, especially when the UN adopted UDHR in I948. Since the discrimination occurs in some places, then some international instruments related to human rights of minority people and migrants emerged such as: the I95I Convention relating to the Status of Refugees, I965 the International Convention on the Elimination of Racial Discrimination (ICERD) (I965), I990 the International Convention on the Protection of the Rights of All Migrant Workers and Members of Their Families (ICPRMWF) (Kjaerum, 2005), and other international law.

The human rights instrument in ASEAN emerged in a unique way because of the consequence of the ASEAN Charter as a binding agreement (Hsien-Li, 20II). This began in 2004 with the Vientiane Action Plan (VAP) 2004, which stated the commitment of member countries to promote and protect human rights as an agenda of cooperation in the political and security pillar(ASEAN_Secretariat, 2004). Then in 2007 , the ASEAN Charter emerged, which wrote a commitment to human rights and also stated the need to create an ASEAN human rights body (Chua \& Lim, 20I7). Then in 20I2, the ASEAN Human Rights Declaration (AHRD) materialized which was divided into seven sections, namely: General Principles; Civil And Political Rights; Economic, Social And Cultural Rights; Right To Development; Right to Peace; Cooperation In The Promotion; And Protection Of Human Rights (Renshaw, 2013).

AHRD was the first specific regional human rights instrument in ASEAN. ASEAN is an intergovernmental organization that emphasizes the principle of no intervention in the internal affairs of each country. It makes the character of the AHRD becomes a soft 
law, or not legally binding for ASEAN member countries. This was driven by the cultural particularism view of member states towards human rights. Consequently, the interpretations between national or regional regions will be different (Bui, 20I6).

Some CSO groups view that the particularism of AHRD is incompatible with universal human rights standards, because it provides a space for interpretation in view of domestic legal jurisdictions (Ismail, 2013). According to Kishore Mahbubani, the differences in the political system and the interests of countries in Asia, especially the economy and development, their views on human rights are not the same as western countries (Mahbubani, 2009). However, the authors argue that the adoption of ADHR as a soft-law is the first step in ASEAN's serious commitment to the promotion and protection of human rights amidst the different social, political, and economic background conditions of ASEAN member countries.

As a form of implementing its commitment to human rights, ASEAN also formed several bodies aimed at promoting political development that prioritizes the principles of democracy and respect for human rights (Hadiprayitno, 20I9). The structure can be seen in the chart below:

Chart I: ASEAN Human Rights Actors
The chart illustrates that there are three main bodies dealing with human rights issues in ASEAN, namely the ASEAN Intergovernmental Commission on Human Rights (AICHR), the ASEAN Committee on Migrant Workers (ACMW), and the ASEAN Commission for the Protection of Women and Children Rights (ACWC).

First, the AICHR was formed in 2009 as a body that is responsible to promote and protect human rights in the region through a dialogue forum among the stakeholders such as member states, academics, and CSOs. AICHR was designed only as a consultative body, and input from AICHR is accepted through a consensus system. Besides that, the members are nominated by their respective countries; it makes AICHR cannot act independently (Hadiprayitno, 20I9).

The second, ACMW, was formed in 2008 as a body tasked with encouraging the implementation of the 2007 Cebu Declaration on the rights of migrant workers by encouraging three actions, step-up, strengthening and cooperating by compiling various policies related to migrant workers' management policies and strengthening information services to educate migrant workers. Secondly, strengthen by increasing the administration of migrant workers. And third,

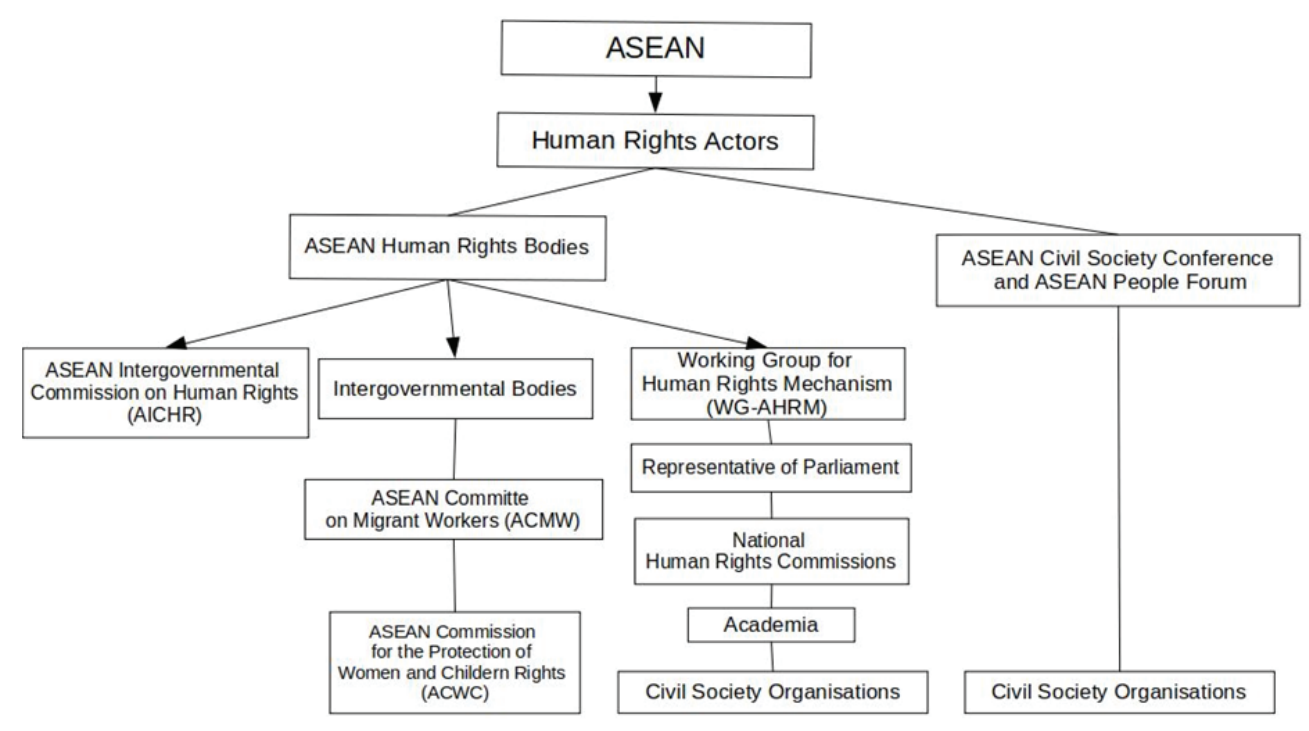

Source: Hadiprayitno, (2019) 
in cooperation with the fight against trafficking in people in ASEAN by coordinating through the Senior Officials Meeting on Transnational Crime (SOMTC) and developing instruments for protecting migrant workers (ASEAN, 2008).

Third, the ASEAN Commission on the Promotion and Protection of the Rights of Women and Children (ACWC) is an intergovernmental body and part of the ASEAN organizational structure. This commission was established in 2OIo related to CEDAW and CRC ratification of AMS. The main purpose of this commission is to protect the basic rights of women and children in the region. Moreover, the characteristic of ACWC is a consultative body whose members consist of two people and are governments representative. The leader elected rotates alphabetically (name of the states) every three years (Pisanò, 2018). The provisions between AICHR and ACWC are almost similar, but the members of ACWC are more diverse, because some of the members are representatives of NGOs and academics, and since their functions are more related to women's issues, the majority of members are women (Petcharamesree, 20I8).

This paper will discuss three types of migration governed in ASEAN, namely workers migration, human trafficking and smuggling, and refugee and displaced persons. To identify the prospects for migration governance, the authors will look into four components of governance: policies, organizational bodies, implementation processes, and challenges in the implementation process.

\section{ASEAN governance on human-traffcking and smuggling}

Human-trafficking, according to the United Nations, is a crime of trafficking human beings through the process of recruiting, sending, transferring, collecting, or receiving human beings for later sexually exploited, forced to works with slavery form or take the organs to get the fee. The mode used by the perpetrators is using fraud, kidnapping, or abuse of power (Hastie, 20I3). Human trafficking crimes can happen to anyone, but women and children are the most vulnerable groups to become victims of these crimes. Coercion and exploitation are important elements that distinguish human trafficking from smuggling, while smuggling only covers the activities of providing illegal transportation migrants across international borders to get compensation (Dinh et all, 20I9).

According to Kok (20I0), a person's desire to migrate may be driven by extreme low-income family conditions, which raises the desire to support the family economy. According to Goździak (20I6), a person is usually dragged into the path of trafficking because of economic motives, to get a job with more income by working abroad. In some cases, the victim did not know that the party helping her was a human trafficking syndicate (Pertiwi, 20I8). It can be said that trafficking is the result of a failed migration in searching for better economic opportunities (Dinh et all, 20I9). Interestingly, child victims are rarely forced victims because most of them are trafficked by parents or their relatives (Goździak, 20I6).

There are four conditions which can drag a person to become a trafficking victim. First, poverty conditions make a person unable to meet basic needs and as a way out of poverty someone can become either a trafficker or a victim. Second, globalization which facilitates the entry of goods, investment, and people due to reduced border controls by the government, creates a gap exploited by traffickers. Third, the lack of recognition of women's rights in the social sphere that causes them to be limited in accessing education making them dependent and considered as an object. Fourth, the low level of education that makes someone lacking insights and information. Thus, when faced with economic hardship, people can think that migrating is the only way out without understanding safe procedures, leading them to become victims of trafficking (lzudin, Tanjung, Trianda, \& Ayusti, 20I9).

The human trafficking issue is one of the significant problems experienced by ASEAN member countries because almost all member countries become suppliers of a human trafficking victim, except maybe Malaysia and Singapore (Meidi Kosandi \& Kartini, 2015). More than 25 million trafficking victims spread 
across the Asia and Pacific region, including in Southeast Asia (Caballero-Anthony, 2018). Victims from the Philippines alone accounted for around I,839 victims, while Thailand became a destination for traffickers to supply victims who work as sex workers (The-ASEAN-Post, 2019).

In the ASEAN region, the majority of human trafficking victims work as migrant workers in $3 \mathrm{D}$ (dirty, dangerous, and difficult) characteristic jobs such as domestic workers, construction, the fishing industry in international waters, and agriculture (Kranrattanasuit, 20I4) mostly as forced labors (Dinh et all, 20I9). Based on the US Department of Trafficking in Person Report, the majority of AMS is still in the category of tier 2. It means that AMS still does not meet the minimum standards of human trafficking victim protection that refer to the Trafficking Victims Protection Act (TVPA) (US_Department_of_State, 20I9). However, for more than a decade, ASEAN has tried to fight against human trafficking issues by developing regional instruments and establishing the intergovernmental body for the Promotion and Protection of Trafficking Victims (Kranrattanasuit, 20I4).

The human trafficking and smuggling in ASEAN, is more seen as traditional security issues. This issue is considered as something that will affect regional stability, and it is linked to terrorism and other organized crime and often discussed in the ASEAN Regional Forum (ARF) (Meidi Kosandi \& Kartini, 2015). The initial settlement of this issue is included in the cooperation agenda of transnational organized crime. The policy instrument for handling human trafficking and smuggling actions refers to the Palermo Protocol, but two out of ten ASEAN members have not ratified the Protocol.

Nevertheless, there are four regional instruments that can be used to govern human trafficking and people smuggling. The first instrument is the ASEAN Declaration on Transnational Crime instrument of policy, agreed on 20 December I997, in the first ASEAN Conference on Transnational Crime. This declaration refers to the decision of the 29th and 30 th ASEAN Ministerial Meeting on various crime issues, including illegal migration and trafficking people. The declaration agreed to discuss the transnational issues to conduct a meeting at least every two years and the need for mutual agreement for legal assistance both in bilateral and multilateral frameworks (ASEAN, 2012a).

The second is the Hanoi Declaration, which was agreed on 16 December I998, at the Sixth Summit. This declaration addresses explicitly the issue of extraordinary crime and human trafficking included in the categories as listed in article 26 (ASEAN, 2012b). The third is the ASEAN Declaration Against Trafficking in Persons Particularly Women and Children agreed on 29 November 2004. A specific policy to combat human trafficking in particular women and children. This declaration mentions some efforts to solve human trafficking issue, such as: developing a network of focal points; enhancing the integrity of official migration documents; sharing views and information on migration; tightening border controls; humanitarian protection on victim handling; and taking coercive action against perpetrators (ASEAN, 2004b).

The fourth is the ASEAN Convention Against Trafficking in Persons, Especially Women and Children (ACTIP), agreed on 2I November 2015 in Malaysia. This convention was created as a form of cooperation among member states in sharing the responsibility to prevent, combat, and punish the traffickers, and to protect their victims without discrimination, especially women and children. One of their efforts is handling victims to return them to the community by involving various stakeholders, including NGOs (Association of Southeast Asian Nations (ASEAN), 20I6). The ACTIP is complemented by the ASEAN Plan of Action Against Trafficking in Persons, Especially Women and Children (2015), as a technical plan related to combating trafficking in persons (ASEAN, 2015).

The ASEAN body in charge of dealing with human trafficking issues are namely AICHR, ACWC (Nasu, McLaughlin, Rothwell, \& Tan, 
2019), and ACMW. In implementing their duties, the ACWC coordinates with the AICHR and can consult with international institutions on the issue of women's and children's rights (ASEAN, 20Io; Kranrattanasuit, 20I4; Pisanò, 20I8) including trafficking in persons, where victims are usually women and children. This can be seen from one of the legal bases, VAP 2004 and its Work Plan for 2016-2020 which addresses traffic issues in person in its themes (ASEAN, 2OI8).

At the national level, handling human trafficking and smuggling is run by the authority of the respective countries. Some member countries have established institutions to tackle the issue, for example, Indonesia with $\mathrm{P}_{2} \mathrm{TP}_{2} \mathrm{~A}$ (Integrated Service Center for the Protection of Women and Children) which operates autonomously and focuses on women and children; Malaysia handled by SUHAKAM; Singapore with the Inter-Agency Taskforce on Trafficking in Persons that consist of seven national institutions (Singapore MOM, 2019); Thailand with Task Force to Combat Trafficking in Person (TATIP); Laos The National Steering Committee on Human Trafficking (NSC) is an inter-agency body headed by the Minister of Public Security (MPS) (UN-ACT, 2019). Meanwhile several other countries' governments, such as Brunei, Cambodia, Vietnam, and Myanmar, have not shown significant efforts to address the issue of human trafficking and smuggling.

For the challenges, since ASEAN is an intergovernmental organization that prioritize the principle of non-interference, hence it results in non-binding policies and efforts toimplement and handle the issue has been on a slow pace.

\section{ASEAN governance on Migrant Workers}

The primary reason of migration of workers is the differences in wages and the probability of finding work (Battistella, 20I4; Keeley, 2009). Therefore, the migration of workers is commonly a movement from developing countries to rich countries (Keeley, 2009).
Since 1970, countries in the Asian region, including Southeast Asia, have become the receiving countries of migrant workers. I with the state having a significant role in determining the migration system with relatively tight policies. At the same time, the majority of ASEAN member countries have been sending migrant workers to the Middle East and East Asia. For intra-regional migration in ASEAN, there are two patterns. The first is countries of the Mekong River, which are Cambodia, Lao PDR, Myanmar, and Vietnam, with Thailand as their destination. Second, the Malay Peninsula region of Brunei Darussalam, Malaysia, and Singapore with migrant workers from Indonesia and the Philippines. Malaysia is a country that relies on cheap labor for the agriculture and manufacturing sectors; almost all migrant workers in Malaysia are semiskilled or unskilled with low levels of education. Whereas Singapore was the first country in the region to impose a foreign labor import policy for manufacturing workers and the personal service sector because of their low fertility rate, and the majority of its migrant workers were unskilled. (Pasadilla and Abella, 20I2). In the stages of the recruitment process of these migrant workers, private intermediaries are involved (Yazid, 2013) to get job channels and information (Abella, 2004), who frequently draws money from migrants (Aldaba, 20I4). ASEAN migrant workers are also dominated by women because the employment sector requires female roles such as nurses, domestic workers, caregivers, and hotel services (Battistella, 20I4). Unfortunately, ASEAN has not had comprehensive governance that can protect migrant workers when they have to face a situation of being undocumented or protecting their fundamental rights while they are working in the destination country.

The emergence of migrant workers' governance coincides with the 2007 ASEAN Charter birth, which aims to form an ASEAN community with three pillars, namely ASEAN Political-Security Community (ASCC), ASEAN Economic Community (AEC), and ASEAN Socio-cultural Community (ASCC). The liberalization of workers flows, especially the skilled labor category, following the AEC framework 
is believed to bring advantages for ASEAN member states because when they open the labor market access, it will increase remittance flows to sending states (Aldaba, 20I4), and help the labor crisis in receiving countries (Keeley, 2009).

Currently, there are at least three regional policy instruments for migrant workers, namely: ASEAN Declaration on the Protection and Promotion of the Rights of Migrant Workers 2007, the ASEAN Socio Cultural Community (ASCC) Blueprint 2007, and the ASEAN Consensus on the Protection and Promotion of the Rights of Migrant Workers 20I7. First is the ASEAN Declaration on the Protection and Promotion of the Rights of Migrant Workers, agreed in Cebu, Philippines on January I3, 2007. This declaration is ASEAN's first instrument on the issue of migrant workers, and the instrument refers to several international conventions such as CEDAW to protect women migrant workers and the Convention on the Rights of the Child to protect children from economic exploitation. It is divided into four parts, namely principles, obligations of recipient countries, obligations of sending countries, and ASEAN commitments in handling migrant worker protection. Nevertheless, similar to other ASEAN policy instruments, this declaration instrument is dependent on the willingness of respective countries to adopt and does not accommodate undocumented migrants. The declaration, however, does encourage the initiatives member countries to share data related to migrant workers and to improve policies and programs related to migrant workers both in receiving and sending countries. It also declared that ASEAN is going to establish further instruments to promote and protect migrant workers' rights (ASEAN, 2007).

The Second is ASCC blueprint, which was agreed by ASEAN on November 20, 2007, at the XIII Summit. ASCC is one of the pillars of the ASEAN Community, which has six main agendas, namely human development, health, and social protection, justice, and social rights, ensuring a sustainable environment, building ASEAN identity, and narrowing the development gap. The agenda for the protection of migrant workers is contained in the specific agenda of social protection (B2) point X, "strengthening cooperation to protect female migrant workers." The outline of the protection of migrant workers is in the agenda of justice and social rights for all people, especially vulnerable groups such as migrant workers. This Blueprint reaffirms the the implementation of the points in the 2007 Cebu Declaration by operating ACMW under SLOM and institutionalizing the ASEAN Forum on Migrant Labor (ASEAN Secretariat, 2009).

The third is the ASEAN Consensus on the Protection and Promotion of the Rights of Migrant Workers, signed by ASEAN member states on November I4, 20I7, at the 3Ist ASEAN Summit in Manila, Philippines. The consensus is a follow-up instrument, which is the mandate of the 2007 Cebu Declaration. Different from the Declaration, this instrument states the protection of undocumented migrant workers which are wrongly caused by entities other than the migrant workers themselves. It contains 62 articles divided into four parts, namely the obligations of the recipient country, the obligations of the sending country, the joint commitment of ASEAN, and the amendment section. As a whole, the instrument is non-discriminative to all migrant workers and accommodates family unification. However, since it is considered as soft law, it is not legally binding (Septiyana, 2018).

The most important ASEAN human rights body is ACMW due to its mandate of ensuring the implementation of the Cebu Declaration and facilitating the development of regional instruments for the protection and promotion of migrant workers' rights. In ensuring the implementation of the Cebu Declaration, since 2008 the ACMW has held the ASEAN Forum on Migrant Labor (AFML) which brings together three stakeholders, namely the government, employers and migrant workers representation involving the ASEAN Secretariat, and international organizations such as the ILO, IOM and UN Women (ASEAN, 2019; ILO, 2013).

In developing regional instruments, ACMW facilitates civil society organizations in drafting a regional policy on migrant worker protection adopted by ASEAN in 2017 to be a 
Consensus (Septiyana, 20I9). Moreover, ACMW arranges programs such as the Reintegration Program for Returning Workers, Studies on Demand and Supply of Migrant Workers in sending and receiving countries, and Studies on Social Security Portability for Migrant Workers in All ASEAN Member Countries (ILO, 2019; Valenciano, 20I7) and organizes a variety of dialogues among stakeholders on the issue of migrant workers, including with AICHR (US-Mission-to-ASEAN, 2019).

Institutionally and instrumentally, the regional governance of migrant workers within ASEAN do exist. However, due to the non-binding characteristics of ASEAN policies, the implementation of the governance depends greatly on the will of the member countries (Pramudyani, 2019). Besides, the problem of undocumented migrant workers, such as most migrant workers in Thailand from Cambodia, Lao PDR, and Myanmar (Pasadilla et all, 20I2), is still an issue. Also,, there are still cases of migrant workers who lose their residence permit and become undocumented in Malaysia, Singapore, and Brunei. The continuous existence of undocumented migrant workers and the non-binding character of the instrument themselves are challenges for the implementation of migrant workers' governance in ASEAN, primarily in protecting the migrant workers' fundamental rights.

\section{Contemporary migration problem in ASEAN: forced migration, displaced Person and refugee}

Refugees and displaced persons are people who are forced to leave their countries because they cannot stay in their homes due to factors such as the threat of persecution (Keeley, 2009). In South East Asia, this is what occur in Myanmar to Rohingya people. The Rohingya community is a group that has not been recognized as a citizen by Myanmar since I948. Many of them are experiencing political violence executed by the Myanmar government, such as physical violence, torture, their women raped, their homes burned, mass killed to drive them away from their land. Until 2017 more than I,00o Rohingya people have died, and more than
200 thousand of them have fled to neighboring countries (Sultana, Busyairi, \& Mclntyre-Mills, 20I9). Rohingya is a group of indigenous people who live in the land called Arakan, which is known today as Rakhine State (Perla \& Ullah, 20I9). The alienation of the Rohingya people has happened since I 855 when the British take over the land and employ the Rohingya people as low-paid farm laborers. During World War Two the Arakan people were divided into two groups who were pro Japanese and British, and the British encouraged the Rohingyas to support them with the promise to give sovereignty over the territory. During the struggle for Myanmar's independence in I942, Myanmar military forces took over Arakan, and Muslim groups who were police and military were replaced and banned in the society (Sultana, Busyairi, \& McIntyre-Mills, 2019). The vertex was in 1982 when Myanmar declared its national law to deny the citizenship of the Rohingya community. Until now, they are stateless groups, socially excluded, marginalized, and denied their human rights (Perla \& Ullah, 20I9; Sultana et al., 2019). In 2017 Myanmar conducted a cleaning operation which was triggered by Rohingya insurgent, who attacked thirty police posts aggressively as a counterwork to get their rights (Barua, 20I8). Many views that what the Myanmar government has done is an act of political violence that violates human rights with the occurrence of genocide to the Rohingya community (Cheesman, 20I7). To save their lives, these Rohingya people flee to the neighboring countries such as Bangladesh, Nepal, Thailand, Malaysia, and Indonesia.

According to Islam (2019), three factors cause human rights violations against the spiritual community, namely: the structure and setting of domestic politics, the weak independence of civil society, and the strength of domestic legal institutions. A state-controlled by the military fully controls the internal political structure. Therefore, the role of CSOs as a counter-hegemony in protecting human rights interests is weak, including the role of the National Human Rights Commission. The strength of domestic institutions has also enabled the Myanmar government to disseminate 
information that form negative public opinion about the Rohingya community (Islam, 20I9).

The Rohingya humanitarian problems in Myanmar has become an essential focus for ASEAN. As stated by Koffi Anan, the Rohingya conflict has caused three grave problems: development, human rights, and security crisis for its people (Fajar, 20I9). ASEAN needs a comprehensive policy for Rohingya refugees, which is expected to create pressure to stop the violence (Sharma, 20I7). The governments of Indonesia and Malaysia have been pushing for regional settlement through ASEAN. Indonesia tried to mediate the Rohingya issue between Myanmar and Bangladesh at the 2016 Meeting of the ASEAN Foreign Ministers in Myanmar (Barua, 2018). The response of the Indonesian government toward the problems was influenced by pressure from Muslim groups in the country for the Indonesian government to assist the Rohingya community. Whereas Malaysia as a country with a majority Muslim population also tried to get involved in dealing with Rohingya issues in the Organization of Islamic Cooperation meeting (Fajar, 20I9).

ASEAN member countries see that the Rohingya conflict is a complicated matter to be dealt with regionally because the issue is a sensitive issue for the Myanmar government. After all, it is considered a 'domestic problem.' ASEAN Way principles ofnon-intervention and consensus that prioritizes state sovereignty make it difficult for member countries to interfere in Myanmar's domestic affairs. Therefore, ASEAN can only provide humanitarian assistance through non-governmental channels (Fajar, 2019). Until now, the handling of Rohingya issues tend to be limited to efforts through transnational civil society channels. They have succeeded in raising awareness of the international community about the critical human rights violations experienced by the Rohingya people, and also channeling humanitarian assistance.

One of the responses come from the ASEAN Parliamentarians for Human Rights (APHR), which is a network of civil society organizations (APHR, 2013). The APHR urges the
International Criminal Court to immediately investigate the Myanmar government regarding the Rohingya issue (Utomo, 2018). Whereas at the regional level, there are no ASEAN human rights bodies such as AICHR or ACMW that have officially expressed their concern on this Rohingya issue. With the currently limited institutional responses toward this issue, there needs to be more efforts made by non-state entities to influence ASEAN leaders through ASEAN affiliated discussion forums. More public discussions should be conducted to create narratives and find possible solutions which can then be submitted to the leaders of member states as policy input to produce new regional policies related to displaced persons and refugees.

At present, a short term solution for the issues related to forced migration, refugees, and displaced persons, ASEAN should optimize the role of existing regional bodies such as ACMW, $\mathrm{ACWC}$, and AICHR. Creating a new specific regional body is unlikely to bring any significant immediate impact since the main obstacle is still the non-cooperative stand of the Myanmar government.

\section{CONCLUSION}

ASEAN, as a regional institutional actor in the migration governance has not been able to comprehensively deal with the current issues of migration in the region. It has shown relative improvements inestablishing regional policy instruments and regional bodies to govern the issues of human trafficking and migrant workers. On the issue of human trafficking and migrant workers, ASEAN member countries were more likely to see it from a security perspective than human rights. Gradually, with the influence of civil society, the problem of human trafficking and migrant workers has now been addressed using the human rights approach. It can be seen from the establishment of ASEAN bodies that function to deal with the issue of migration as human rights bodies such as AICHR, ACWC, and ACMW.

Unfortunately, since ASEAN has to conduct governance based on the non-intervening 
principle, it tend to produce non-binding soft-law. Moreover, there are still overlapping functions between the existing regional bodies that deal with the issues of migration, which are actually potential to be turned into a more comprehensive governance, given better coordination.

Whereas in the issue of displaced persons and refugees, particularly concerning the Rohingya conflict in Myanmar, ASEAN has not yet issued an official stance that resulted in a comprehensive regional policy related to this matter. Since the policy-making system requires consensus, which usually takes a long time, ASEAN needs to employ the existing instruments and bodies in dealing with the issues of displaced persons while continuing to seek for more cooperative reaction from the government of Myanmar. For the meantime, ASEAN Human Rights Declaration can be utilized as an instrument to ensure the protection of the human rights of the refugees. Also, AICHR, as an intergovernmental body, needs to be more pressing toward Myanmar as one of the member countries to reduce the intensity of political violence and provide advice to the Minister and head of state to immediately find alternative solutions related to the Rohingya issue. Meanwhile, ACWC as a commission for protecting the rights of women and children needs to be involved in the handling of displaced persons because they are a vulnerable group to become the victims of human trafficking with several cases of abduction of women and children in the Refugee Camp.

In conclusion, the governance of migration in Southeast Asia through ASEAN definitely requires the support from more specific instruments and regional bodies. However, given the current condition that the implementation of current policy instruments and the work of regional bodies are still very much restricted due to the non-intervening principles and the noncooperative stands of the specifically involved ASEAN member states, creating new instruments and regional bodies might not be the best options. At present, intensified dialogues which allow more involvement of and inputs from non-state entities to find alternative solutions which are relatively acceptable for all parties is crucial. The intergovernmental nature of ASEAN should not prevent it from collaborating with non-state partners in addressing the issues of migration in the region.

\section{REFERENCES}

Abella, M. I. (2004). The Role of Recruiters in Labor Migration. In International Migration: Prospects and Policies in a Global Market. https://doi.org/I0.I093/or99269009.003.00II

ADB. (20I8). Greater Mekong Subregion. https://doi. org/I0.I355/97898I4379694

Aldaba, F. T. (2014). Global and Asian Perspectives on International Migration (G. Battistella, Ed.). https://doi.org/I0.I007/978-3-3I9-083I7-9

APHR. (2013). About APHR. Retrieved October I8, 20I9, from https://aseanmp.org/about-aphr/

ASEAN. (2004). ASEAN Documents Series. Retrieved from https://www.asean.org/storage/images/ archive/ADS-2004.pdf

ASEAN. (2004a). ASEAN Declaration Against Trafficking in Persons Particularly Women and Children. Retrieved October 22, 2019, from asean.org website: https://asean.org/ asean-declaration-against-trafficking-inpersons-particularly-women-and-children-4/

ASEAN. (2007). ASEAN Declaration on the Protection and Promotion of the Rights of Migrant Workers. Asia-Pacific Journal on Human Rights and the Law, 8(2), 85-89. https://doi. org/IO.II63/I57I8I507783877069

ASEAN. (2008). ASEAN Committee on the Implementation of the ASEAN Declaration on the Protection and Promotion of the Rights of Migrant Workers (ACMW) Work Plan. , 8 Asia-Pacific Journal on Human Rights and the Law.

ASEAN. (20Io). TOR The ASEAN Commission on the Promotion and Protection of the Rights of Women and Children.

ASEAN. (20I2a). ASEAN Declaration on Transnational Crime Manila, 20 December I997. Retrieved October 29, 2019, from asean.org website: https://asean.org/?static_post=asean-declaration-on-transnational-crime-manila20-december-I997

ASEAN. (2012b). Ha Noi Declaration of I998 I6 December 1998. Retrieved October 29, 20I9, from asean.org website: https://asean. org/?static_post=ha-noi-declaration-ofI998-I6-december-I998 
ASEAN. (20I5). ASEAN Plan of Action Against Trafficking in Persons, Especially Women and Children.

ASEAN. (2018).Work Plan 2016-2020: The-ASEANCommission-on-the-Promotion-and-Protection-of-the-Rights-of-Women-and-Children$A C W C$.

ASEAN. (2019). ASEAN Labor Ministerial Meeting (ALMM). Retrieved October I7, 2019, from asean.org website: https://asean.org/ asean-socio-cultural/asean-labour-ministersmeeting-almm/overview/

ASEAN Secretariat. (2009). ASEAN Socio-cultural Community Blueprint. In ASEAN Sociocultural Community Blueprint. https://doi. org/Io.IoI7/CBO978II074I5324.004

Association of Southeast Asian Nations (ASEAN). (2016). ASEAN Convention Against Trafficking in Persons, Especially Women and Children.

Barua, T. (2018). Efforts Of Indonesian Government Towards Bangladesh For Dealing With Refugee Problem. (Master Thesis: Universitas Katolik Parahyangan). Retrieved from http://repository.unpar.ac.id/bitstream/ handle/I23456789/8645/Cover-Babi85116004sc-p.pdf?sequence $=$ I\&isAllowed $=y$

Battistella, G. (20I4). Migration in Asia: In Search of a Theoretical Framework. In G. Battistella (Ed.), Global and Asian Perspectives on International Migration. https://doi.org/Io.Ioo7/978-3-3I908317-9

Betts, A. (20II). Introduction: Global Migration Governance (A. Betts, Ed.). https://doi.org/ro.I093/ acprof:os o/9780199600458.ool.ooor

Borzutzky, S. (2003). Are Promises All We Can Offer?: Globalization, Poverty, Inequality, and Human Rights. In W. Driscoll \& J. Clark (Eds.), Globalization and the Poor: Exploitation or Equalizer? (pp. 25-3I). New York: The International Debate Education Association.

Boughton, J. M., \& Jr, C. I. B. (2007). No Title. Retrieved October 30, 2019, from imf.org website: https://www.imf.org/external/pubs/ $\mathrm{ft} /$ fandd/2007/I2/boughton.htm

Bui, H. (20I6). The ASEAN Human Rights System: A Critical Analysis. Asian Journal of Comparative Law. https://doi.org/Io.IoI7/asjcl.20I6.9

Caballero-Anthony, M. (2018). A Hidden Scourge: Southeast Asia's refugees and displaced people are victimized by human traffickers, but the crime usually goes unreported.

Chua, D., \& Lim, E. (20I7). The ASEAN Charter. In ASEAN 50 (pp. I02-I48). https://doi. org/Io.II42/978981322II47_0oo5
Cheesman, N. (20I7). How in Myanmar "National Races" Came to Surpass Citizenship and Exclude Rohingya. Journal of Contemporary Asia, 47(3), 46I-483. https://doi.org/Io.Io8o/ 00472336.2017 .1297476

Dinh, N., Hughes, C., Hughes, J., \& Maurer-Fazio, M. (20I9). Human Trafficking in Southeast Asia: Results from a Household Survey in Vietnam. Journal of Human Trafficking, I-2I. https://doi. org/I0.1080/23322705.2019.1650527

Fajar, M. D. (2019). Tekanan Kelompok Islam dan Praktek Norma Non-Intervensi ASEAN dalam Pertimbangan Kebijakan Luar Negeri Indonesia. Studi Kasus: Bantuan Kemanusiaan terhadap Rohingya di Myanmar. Master Thesis: Univeristas Katolik Parahyangan.

Fawcett, L. (2008). Regional Institution. In P. D. Williams (Ed.), Security Studies: An Introduction. Oxon: Routledge.

Finkelstein, L. S. (I995). Global Governance. I(3), 367-372.

Goldin, I., \& Reinert, K. (2007). Globalization for Development: Trade, Finance, Aid, Migration and Policy. New York: Palgrave Macmillan.

Goździak, E. M. (20I6). Contested Childhoods: Growing up in Migrancy. In M. L. Seeberg \& E. M. Goździak (Eds.), Contested Childhoods: Growing up in Migrancy Migration, Governance, Identities. https://doi.org/Io.Ioo7/978-3-3I9446I0-3

Guzzini, S. (2012). The Ambivalent 'Diffusion of Power' in Global Governance. In S. Guzzini \& I. B. Neumann (Eds.), The Diffusion of Power in Global Governance. https://doi. org/10.1057/9781137283559

Haas, E. B. (1958). The Challenge of Regionalism. International Organization, I2, 440-458.

Hadiprayitno, I. (20I9). Deadlock and Denial: Domestic Challenges and the Institutionalization Human Rights in ASEAN. Global Jurist. https://doi.org/I0.I5I5/gj-20I8-OooI

Hastie, B. (2013). Disciplining the Transnational Mobility of People (M. Geiger \& A. Pécoud, Eds.). https://doi.org/10.1057/9781137263070

Hsien-Li, T. (2OII). THE ASEAN INTERGOVERNMENTAL COMMISSION ON HUMAN RIGHTS: Institutionalising Human Rights in Southeast Asia. Cambridge, UK: Cambrdige University Press.

ILO. (2013). ASEAN Forum on Migrant Labour: Background Information. https://doi.org/Io.IoI7/ CBO978II07415324.004 
ILO. (2015). Analytical report on the international labour migration statistics database in ASEAN: Improving data collection for evidence-based policy-making. Thailand.

ILO. (20I9). Workshop on Reintegration Programmes for Returning Migrant Workers. Retrieved October I8, 20I9, from https://www.ilo.org/ asia/events/WCMS_7I3765/lang--en/index. htm

IOM. (20I9a). Child and Young Migrants. Retrieved from Migration Data Portal website: I3 October 20I9, from https://migrationdataportal. org/themes/child-and-young-migrants

IOM. (20I9b). Forced Migration or Displacement. Retrieved October I3, 2019, from Migration Data Portal website: https://migrationdataportal.org/themes/labour-migration

IOM. (20I9c). RETURN AND REINTEGRATION KEY HIGHLIGHTS 20I8. Retrieved Retrieved October I3, 20I9, from https:// www.iom.int/sites/default/files/our_work/ DMM/AVRR/20I8_return_and_reintegration_key_highlights.pdf

IOM. (2oI9d). Themes. Retrieved October I4, 20I9, from Migration Data Portal website: https:// migrationdataportal.org/search?text=\&them e $=$ I987\&tags $=$ \&category $=$

Islam, M. S. (20I9). Understanding the Rohingya Crisis and the Failure of Human Rights Norm in Myanmar: Possible Policy Responses. Jadavpur Journal of International Relations, 23(2), I58-I78. https://doi.org/Io.II77/o9735984I9862482

Ismail, S. M. (20I3). We Do It Our Way? Investigating the Recently Adopted Asean Declaration of Human Rights 20I2 and Predicting the Future of Human Rights Law in South East Asia. Paper presented at International Conference on International Relations and Development (ICIRD) \& Chulalongkorn University, Bangkok, Thailand. Bangkok: Chulalongkorn University. August 22-23, 2013.

Izudin, A. N., Tanjung, I., Trianda, R. W., \& Ayusti, I. (2019). Analysis of Human Trafficking in Asean. (201606I04I2), I4-I5.

Keeley, B. (2009). International Migration: The human face of globalisation. Retrieved from www. oecd.org/dataoecd/I/15/43695854.pdf

Kjaerum, M. (2005). Human rights for immigrants and immigrants for human rights. In International Migration and Security: Opportunities and Challenges (pp. 5I-63). https://doi. org/I0.4324/978020323658I
Köhler, J. (20II). What government networks do in the field of migration: An analysis of selected Regional Consultative Processes. In R. Kunz, S. Lavenex, \& M. Panizzon (Eds.), Multilayered Migration Governance: The promise of partnership (pp. 88-II5). London and New York: Routledge.

Kranrattanasuit, N. (20I4). Asean and human trafficking: Case studies of Cambodia, Thailand and Vietnam. In International Studies in Human Rights (Vol. Io9). Leiden, The Netherlands.: Koninklijke Brill nv.

Kunz, R., Lavenex, S., \& Panizzon, M. (20II). Introduction: Governance through partnerships in international migration. In R. Kunz, S. Lavenex, \& M. Panizzon (Eds.), Multilayered Migration Governance: The promise of partnership (pp. I-20). London and New York: Routledge.

Kuptsch, C., \& Martin, P. (20II). Low-Skilled Labour Migration. In A. Betts (Ed.), Global Migration Governance (pp. 2-38). https://doi.org/I0.I093/ acprof:os o/9780199600458.00I.000I

Liow, J. C. (20I8). Can Indonesia Fulfill Its Aspirations to Regional Leadership? In G. Rozman \& J. L. C. Yong (Eds.), International Relations and Asia's Southern Tier: ASEAN, Australia, and India. Singapore: Palgrave Macmilan.

Mahbubani, K. (2009). Can Asian Think? Singapore: Marshall Cavendish International (Asia) Private Limited.

Mahmud, M. T., Khaled, A. F. M., \& Fariba, N. I. (2019). A Conflict Profile: The Rohingya Conflict in Myanmar. Journal of Social Science, I4. https://doi.org/Io.24297/jssr.vi4io.8407

Margaret P Karns, Karen A Mingst, \& Stilles, K. W. (2015). International Organizations: The Politics and Processes of Global Governance (Third). Colorado: Lynne Rienner Publisher, Inc.

Meidi Kosandi, \& Kartini, E. (20I5). Human Trafficking di Asia Tenggara : Mencari Solusi Kolektif Melalui ASEAN. Human Trafficking Di Asia Tenggara: Mencari Solusi Kolektif Melalui ASEAN, (January 2013).

Nasu, H., McLaughlin, R., Rothwell, D. R., \& Tan, S. S. (20I9). Human Trafficking and People Smuggling. In The Legal Authority of ASEAN as a Security Institution (pp. I6I-I90). https:// doi.org/Io.IoI7/978IIo86695II.009

Olivier, M. (2018). Social protection for migrant workers in ASEAN: Developments, challenges, and prospects (first). Geneva: International Labour Organization. 
Pasadilla, G., \& Abella, M. (20I2). Social protection for migrantworkers in ASEAN,. In CESifo Working Paper (No. 39I4). Munich.

Perla, A., \& Ullah, Y. (20I9). Time to Act: Rohingya Voices. Museum Management and Curatorship, 34(6), 577-594. https://doi.org/Io.Io80/09647 775.2019.1682807

Pertiwi, H. F. (20I8). Analisis Modus Operandi Sindikat Women Trafficking (Studi atas Tiga Kasus Human Trafficking dari NTT dan Jakarta ke Malaysia. Jurnal Kriminologi Indonesia, I4(I), I-I3. Retrieved from https://media. neliti.com/media/publications/267426-none4a993300.pdf

Petcharamesree, S. (20I8). ASEAN Human Rights Mechanisms. In G. Oberleitner (Ed.), International Human Rights Institutions, Tribunals, and Courts (pp. I-24). https://doi. org/10.1007/978-98I-10-4516-5_20-I

Pisanò, A. (20I8). The ASEAN Commission on the Promotion and Protection of the Rights of Women and Children. In International Human Rights of Women (pp. I-I7). https:// doi.org/I0.I007/978-98I-I0-4550-9_II-I

Pramudyani, Y. D. (2019). Konsensus ASEAN belum pengaruhi kemajuan perlindungan pekerja migran. Antara News. Retrieved I3 October 20I9, from https://www.antaranews.com/ berita/792679/konsensus-asean-belumpengaruhi-kemajuan-perlindungan-pekerjamigran

Raymer, J., Guan, Q., \& Ha, J. T. (20I8). Estimating annual flows of migration amongst ASEAN countries: Overcoming high levels of missing and inconsistent flow data.

Reinert, E. S. (2004). Introduction. In Globalization, Economic Development and Inequality: An Alternative Perspective (pp. I-20). Cheltenham: Edward Elgar Publishing Limited.

Renshaw, C. S. (20I3). The ASEAN Human Rights Declaration 20I2. Human Rights Law Review, I3(3), 557-579. https://doi.org/Io.I093/hrlr/ ngtor6

Septiyana, I. (2018). Keterlibatan Organisasi Masyarakat Sipil (OMS) Indonesia dalam PembuatanKebijakan Perlindungan Buruh Migran ASEAN (Universitas Katolik Parahyangan). Retrieved from http://repository.unpar.ac.id/bitstream/handle/ı23456789/8627/Cover-Babi89II60o6sc-p.pdf?sequence $=\mathrm{I} \&$ isAllowed $=y$

Septiyana, I. (20I9). The Involvement of Indonesian Civil Society Organizations in the PolicyMaking Process of Migrant Workers Protection in ASEAN. Journal of Indonesian Social
Sciences and Humanities, 9(I), I-I9. https:// doi.org/I0.I4203/jissh.v9iI.72

Sharma, A. (2017). How South Asia is Failing its Rohingya Challenge. Retrieved October I3, 2019, from The Diplomat website: https:// thediplomat.com/20I7/I2/how-south-asiais-failing-its-rohingya-challenge/

Soederberg, S. (2006). Global Governance in Question: Empire, Class, and the New Common Sense in Managing North-South Relations. Ann Arbor: Plutobooks.

Sultana, S., Busyairi, M., \& Mclntyre-Mills, J. (2019). Mixed Methods and Cross Disciplinary Research. In J. McIntyre-Mills \& N. R. A. Romm (Eds.), Mixed Methods and Cross Disciplinary Research: Towards Cultivating Eco-systemic Living. https://doi.org/Io.1007/978-3-03004993-5

Tarling, N. (I999). The Cambridge History of Southeast Asia. In The Cambridge History of Southeast Asia (second). https://doi. org/IO.IOI7/chol9780521355063

The-ASEAN-Post. (2019). ASEAN's human trafficking woes. Retrieved from theaseanpost.com website: https://theaseanpost.com/article/ aseans-human-trafficking-woes

The-Economist. (2003). Grinding the Poor. In W. Driscoll \& J. Clark (Eds.), Globalization and the Poor: Exploitation or Equalizer? (p. 70). New York: The International Debate Education Association.

US_Department_of_State. (20I9). Trafficking In Persons Report. Retrieved from https:// rs.usembassy.gov/state-department-relasestrafficking-in-persons-report-20I9/

US-Mission-to-ASEAN. (2019). National Policy Dialogue on the Implementation of ACMW. Retrieved October I8, 20I9, from usmission. gov website: https://asean.usmission.gov/ national-policy-dialogue-on-the-implementation-of-acmw/

Utomo, H. F. S. (2018). Ratusan Anggota Parlemen Se-ASEAN Desak Myanmar Selesaikan Konflik Rohingya. Retrieved October I8, 20I8, from liputan6.com website: https:// www.liputan6.com/global/read/3627358/ ratusan-anggota-parlemen-se-asean-desakmyanmar-selesaikan-konflik-rohingya

Valenciano, A. Q. (20I7). ASEAN Frameworks on Labour Migration: Migrant Workers' Protection And Labour Mobility. Retrieved from https:// www.unescap.org/sites/default/files/Statement_Philippines_3_a_additional.pdf 
Weiss, T. G., \& Wilkinson, R. (20I4a). Rethinking Global Governance? Complexity, Authority, Power, Change. International Studies Quarterly, 58, 207-2I5. https://doi.org/IO.IIII/ isqu.I2082

Weiss, T. G., \& Wilkinson, R. (20I4b). Rethinking Global Governance? Complexity, Authority, Power, Change. International Studies Quarterly, 58(I), 207-2I5. https://doi.org/Io.IIII/ isqu. 12082
Wynne, M. A. (2015). International Migration Remains the Last Frontier of Globalization. In Economic Letter (Vol. Io). Selangor: Strategic Information Research Development (SIRD).

Yazid, S. (2013). Indonesia's Civil Society in the Age of Democratization: NGO-Responses on the Issue of Labor Migration. Nomos Verlagsgesellschaft. 
